\title{
TANULMÁNYOK
}

\author{
Deák Tamás - Elekes Tibor
}

\section{A bevándorlás jellemzői Japánban a 20. század elejétől napjainkig}

Japán elöregedö társadalma a 2. világháború utáni látványos gazdasági fejlödés munkaerő igényét részben külföldi munkavállalókkal tudja biztositani. A földrajzi közelség és a történelmi kapcsolatok jelentös számú kinai és koreai vendégmunkás érkezését tették lehetővé. Az állam által szervezett, jogi keretek között zajló bevándorlás a közeli ázsiai, kevésbé fejlett országokat érinti, de a folyamat globális jellegét erösíti a távoli kontinensekről származó közösségek jelenléte. Az össznépességen belül a külföldiek aránya 2010-ben 1,7\% (2,1 millió), 2012-ben 1,6\% (2 millió), 2014-ben 1,7,\% (2,1 millió), 2016-ban közel 1,9\% (2,4 millió), napjaikban 2\% feletti a 124 milliós népességü országban.

Kulcsszavak: Japán, gazdasági fejlödés, népességfogyás, bevándorlás JEL kód: J11, J15

https://doi.org/10.32976/stratfuz.2020.10

\section{Bevezetés}

Japán a kevésbé fejlett országok közé tartozott a 19.-20. század fordulóján. A nyersanyagban szegény ország az 1894-1945 közötti időszakban elöször Korea déli részét, Tajvant, kínai városokat és tartományokat, majd a Csendes-óceán térségében elhelyezkedő további területeket foglalt el. Ebben az időszakban a meghódított térségből jelentős számban érkeztek koreaiak és kínaiak a szigetországba. Ezzel egyidőben megjelent a munkaerő kivándorlás, 1908-1940 között több mint kétszázezer japán telepedett Dél-Amerikába, elsősorban a brazíliai ültetvényekhez. (Sugimoto 2009)

A korra jellemző népesedési folyamatok érvényesültek az országban. A magas természetes szaporulatnak köszönhetően jelentősen növekedett a népességszám. 0,5 és 1 millió közötti volt a természetes szaporulat éves értéke ,,a felkelő nap országában” a 20. század első négy évtizedében. Az egész időszakban az 1. világháború jelentett visszaesést, amikor ez az érték 300 ezerre csökkent. (www.stat.go.jp)

Óriási emberveszteség, természetes fogyás jellemezte a 2. világháború időszakát. A háború végén, az elvesztett területekről visszavándorlók problémáira is megoldást kellett találni. A háborút követő újjáépítés gazdasági lehetőségei, az egészségügy fejlődése több mint másfél milliós éves természetes szaporulatot eredményezett az 1950-es évek elején (évente 2,7 millió körüli a születések, 1 millió alatti az elhalálozások száma). (www.stat.go.jp)

A 2. világháború után elfogadott új alkotmány biztosította a nők egyenjogúságát, elösegítette a társadalmi emancipációt, hozzájárult a szabatosabb életforma kialakulásához és a hagyományos családi kötelékek lazulásához. A nők jelentős és a gazdaságba fokozatosan bevont munkaerő utánpótlást jelentettek az iparban, később a tercier és kvaterner szektorban. Az 1950-es évektől, elsősorban a nagyvárosi térségekben fokozatosan növekedett a válások száma. Lassabban, de a vidéki mezőgazdasági térségekben is elterjed a városi életmód, mentalitás. A korábbi évszázadok japán társadalmában az elsőszülött fiúgyermek kötelezettsége volt gondoskodni szüleiről azok haláláig. E kötelezettség miatt gyakran kitolódott időben a házasodás és a családalapítás. E téren is látványos változást hozott a jogi és társadalmi környezet átalakulása. Az 1950-es évek elejére jellemző, „túlnépesedéshez” vezető folyamat enyhítésére elfogadott törvények lehetővé tették az abortuszt. Az évtized második felére, néhány év alatt több mint 30\%-al csökkent a születések száma. (Szentes 2002; Sugimoto 2009; Iijima 2015). 
Évtizedekig tartó, látványos gazdasági fejlődés időszaka kezdődött el a 2. világháborút követő újjáépítéssel. Elkezdődött a változó világgazdasági körülményekhez való erőteljes igazodás, a strukturális alkalmazkodás. Az 1990-es évekig tartó fejlődést mérsékelte az 1970-es évek két olajválsága. (Wallerstein 1983; Szentes 2011) A fejlődő gazdaság munkaerőigényét egyre kisebb mértékben tudta fedezni az ország. Jogi keretek között, szervezett formában, elkezdődött a vendégmunkások nagyobb létszámban történő fogadása. A térség kevésbé fejlett országaiból nagyobbrészt ipari és mezőgazdasági munkára érkezett fiatal munkaerő. Magasan képzett munkavállalók az USA-ból, Nyugat-Európából és Ausztráliából érkeztek. (Wolley 2005; Sugimoto 2009; Iijima 2015)

1980-1990 között megszilárdult a napjaikban ismert Japán polgári társadalom. A mai fiatal generáció a piaci lehetőségek, de ugyanakkor az egyéni igények és a karrier függvényében választja a munkahelyet. A biztos megélhetést, de jelentős kötődést igényelő állásokkal ellentétben a szabadon választható munkahelyeket preferálják. A társadalmi folyamatok függvényében kitolódik a családalapítás időpontja, házasságkötésre többnyire csak a gyerek megszületése után kerül sor. (Sorensen 2002; Mizuuchi 2003; Palanovics 2006; Iijima 2015)

A fejlett egészségügyi ellátás, a magas életszínvonal az 1990-as évek elejéig 700 ezer körüli értéken tartotta az elhalálozások számát. Ezt követően, fokozatosan 1,5 millió fölé emelkedett az évente elhunytak száma a napjaikig tartó időszakban. 2007 után a természetes fogyás a jellemző, az utóbbi években ennek értéke fél millió körüli. Az 1990-es évektől az aktív korosztály számának és arányának csökkenése a jellemző a fokozatosan elöregedö, fogyó népességü társadalomban (www.stat.go.jp) (1.ábra)

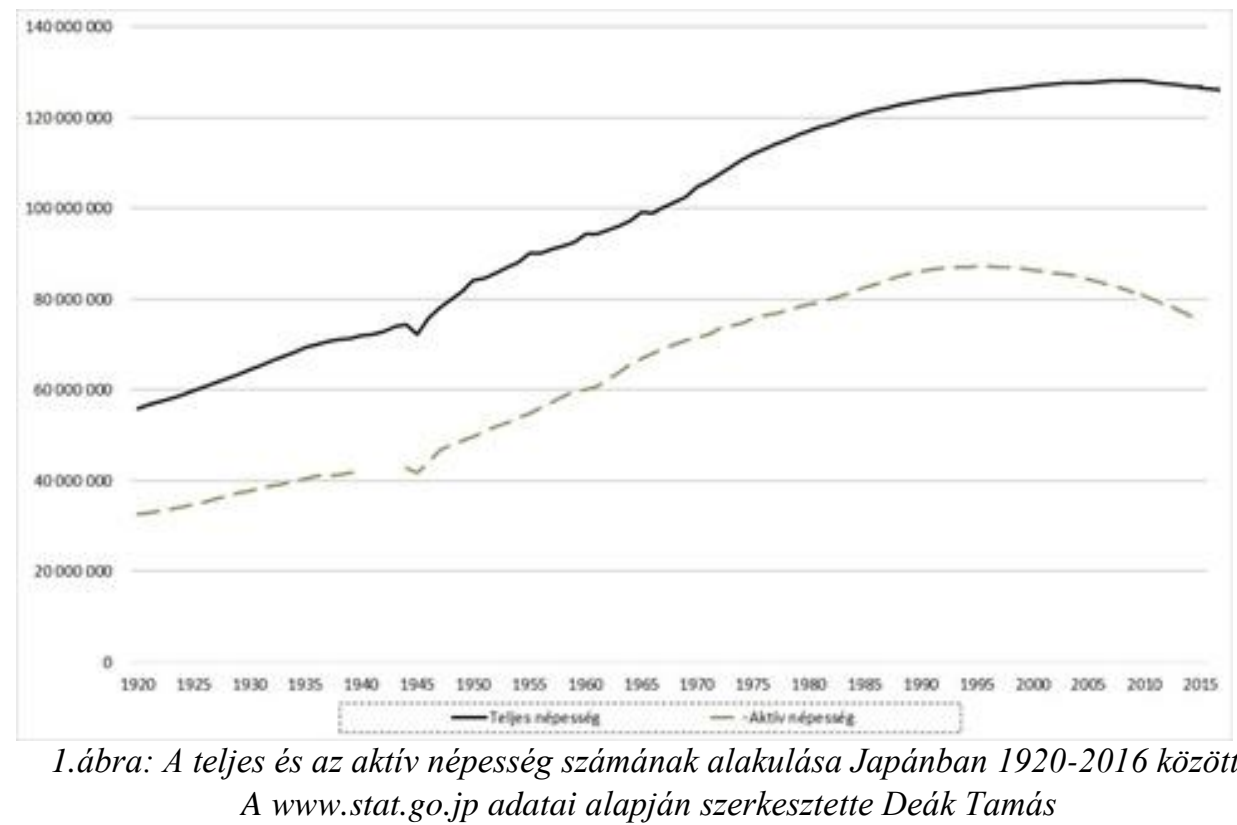

2018-ban a természetes fogyás 448 ezer volt (921 ezer születés és 1,37 millió elhalálozás) a 124 millió lakosú távolkeleti országban. (www.stat.go.jp) Politikai célkitüzésként fogalmazódott meg az 1,8-as termékenységi ráta elérése 2025-re.

Napjaink japán gazdaságában a primer szektor jelentősége 1-2\%-os. A kiterjedt mezőgazdasági területhasználat miatt eléri a 10\%-ot Honshu sziget északi részén. Kisebb mértékü, de jelentős növénytermelő, nagy népsürüségü térségek az Oszaka-, a Kanto- és a Nobi-síkság. Elöregedő mezőgazdasági népesség műveli Dél-Kyushu, Észak-Honshu, és Shikoku síkságait. Az ország gazdaságának 1/3-a a szekunder szektorhoz kapcsolódik. Legjelentősebb az Osaka, Kobe, 
Kyoto térségét magába foglaló Kansai régió, Honshu északkeleti része és Tokió térsége. A mezőgazdasági, a bányászati és az ipari övezetekből a szolgáltatások, valamint a $\mathrm{K}+\mathrm{F}+\mathrm{I}$ felé vándorló fiatal munkaerőt gyakran bevándorlókkal pótolják. A gazdaság hajtóerejének számító tercier és a kvaterner szektor foglalkoztatja a munkavállalók több mint 2/3-át. Többnyire a nagyvárosi térségekben összpontosul: Tokyo, Kanagawa, Chiba (Kanto régió), Osaka, Kyoto (Kansai régió). (Horváth 1998; Sugimoto 2010; Horváth - Szabó - Wilhelm 2010; Deák-Elekes 2019) 2018-ban a 2,4\%-os munkanélküliség az aktív népesség majdnem teljes foglalkoztatottságát és a munkaerő tartalék hiányát jelenti. (http://stats-japan.com)

\section{Külföldiek munkavállalása Japánban}

A felvázolt folyamatok az aktív népesség több évtizede tartó arány- és számbeli csökkenését mutatják. A fejlődő gazdaság a belföldi munkaerő pótlására külföldi munkavállalók alkalmazását igényelte. Az idegenek munkavállalását, betelepülését határozott jogi- és időkeretek között szabályozza az állam. A külföldi, a munkavállalói vízumot országa japán nagykövetségén kérvényezi, majd annak jóváhagyása után, meghatározott időszakra érkezhet Japánba a megjelölt munkahelyre, többnyire a gazdagabb prefektúrákba, a nagyvárosokba.

Évszázadokon át „,zárt közösségekben” éltek, nehezen tolerálták az idegeneket a japánok. Az 1970-es évek gazdasági fejlődése nagyszámú munkahelyet teremtett, betöltésük egyre nagyobb kihívást jelentett. Az 1980-as évektől enyhült a külföldiek munkavállalásának jogi szabályozása. 1990-től további könnyítések léptek életbe, felértékelődött a japán társadalomba könnyebben integrálható diaszpóra szerepe. A külföldre vándorolt japánokat, vagy azok leszármazottjait az anyaországban „Nikkei”-nek nevezik. Közülük sokan már a családban megtanulták az anyaország nyelvét, megismerték kultúráját, így könnyebb a munkavállalói vízum vagy az állampolgárság megszerzése. 2000-ben Brazíliában a brazil-japán kettős állampolgárok száma másfél millió volt. (Sugimoto 2009; Hayashi 2001; Iijima 2015).

Az új vízumrendszer lehetővé tette a külföldre települt japánok másod- vagy harmadgenerációs leszármazottjai számára a 2 vagy 3 évre érvényes, de tovább hosszabbítható, a „hiányszakmákhoz”, konkrét munkaterületekhez kapcsolódó munkavállalói vízum megszerzését. A könnyítések, Japán fejlett gazdasága, a magas életszínvonal, a létbiztonság erős vonzerőt jelentett a Brazíliába, Peruba letelepedett japánok leszármazottjai számára az utóbbi két évtizedben. A japán munkaadók a sajátos munkarend, munkakultúra megismertetését célzó betanítási rendszert dolgoztak ki az országba érkező külföldi munkavállalók számára. A törvényes bevándorlás könnyítésével párhuzamosan szigorították, pénzbírsággal és börtönbüntetéssel sújtják az 1970-es évektől felerősödött illegális migrációt, az illegális bevándorlók munkáltatóit. (Sugimoto 2009; Iijima 2015)

\section{Bevándorlás 2010 után}

Többnyire az ipari-szolgáltatói nagyvárosokban, a fizikai munkát igénylő „hiányszakmákban” helyezkednek el a bevándorlók. Az Észak-amerikaiak, a Nyugat-európaiak, az ausztrálok nagyobbrészt magasabb képzettséget igénylő állásokat töltenek be. Nagyszámú, térségbeli időszakos munkaerőt vonzott a 2020-as tokiói olimpia előkészítése. Jelen tanulmány további része rövid történelmi áttekintés után, a 2010 utáni bevándorlást a Japán statisztikai adatok (www.stat.go.jp; http://stats-japan.com) alapján összegzi kontinensek és kibocsátó országok viszonylatában.

\section{Ázsiai országokból érkezö külföldiek}

1894-ben, az első kínai-japán háború alatt szerezte meg Japán az első jelentősebb szárazföldi területeket, milliós bevándorló tömeg érkezett a Koreai-félszigetről és Mandzsúriából. 1910-ig a Japánban élő koreaiak száma 2,3 millió. (Sugimoto 2010) 
A 2. világháború előtt és alatt további nagyszámú koreai és kínai érkezett a szigetországba. A háború után nagyrészük a többségtől elkülönülő saját kulturális, etnikai társadalmat építve maradt Japánban. Ök a kétnyelvü „Zainchi” koreaiak és kínaiak. A második, harmadik generáció asszimilációja erőteljesebb, többnyire a japán nyelvet használják, a többségi kultúrát élik meg, japán identitásúnak vallják magukat. (Sugimoto 2010)

A Japánba került koreaiak és azok leszármazottjainak visszavándorlási hajlandósága évtizedek során a társadalmi-gazdasági viszonyok, politikai tényezők függvényében változott. A 2 . világháborúban elpusztított Korea, valamint Észak-Korea kommunista rendszere nem kedvezett a visszavándorlásnak. A további kivándorlást ösztönözte a félszigeten 1950-1953 között pusztító háború. Az 1990 utáni nyitottabb japán vízumrendszer érősítette a bevándorlást. Az érkezőknek többnyire az építoiipar és a bányászat biztosította a megélhetést. Az utóbbi évtizedekben a kettős állampolgárság lehetőségének korlátozása a Japánban élő koreaiak visszavándorlását ösztönzi. Ezt a folyamatot erősíti a dél-koreai gazdaság fejlődése. A több generáción át Japánban élő koreaiak a japántól, de a koreaitól is eltérő, nagyobbrészt a befogadó ország nyelvét használó kultúrát alakítottak ki. Asszimilációjuk előrehaladott, de szokásaik, kulturális sajátosságaik, arcvonásaik megkülönböztetik a többségiektől. Évtizedek alatt sokat javult az elfogadottság mértéke a többség és kisebbség között. A több évszázados gazdasági-társadalmi kötődés, a földrajzi közelség miatt napjaikban a második legjelentősebb Japánba „ingázó nemzet” a koreai. Létszámuk sokkal kisebb, mint a korábbi évtizedekben áttelepedett koreaiaké, de jelenlétük szembetűnőbb, elfogadottságuk kisebb mértékü eltérő kultúrájuk, társadalmi megjelenésük miatt. (Sugimoto 2010) 2010-2016 között az asszimiláció, a dél-koreai gazdasági fejlődés biztosította növekvő életszínvonal ösztönözte visszavándorlás és az ingázás erősödésének köszönhetően, több mint 110 ezerrel csökkent a közeli félszigetröl származók száma a „felkelő nap országában”. (1.táblázat, 2.ábra) A tokiói olimpia elökészítő munkálataiba is többnyire az ingázó koreaiak kapcsolódtak be.

Hasonlóan alakult a kínaiak bevándorlása egy évszázad politikai, társadalmi, gazdasági eseményeinek függvényében. Az első nagy bevándorlási hullám az első (1894-1895) és a második (1937-1945) kínai-japán háború időszakához kapcsolódik. A mandzsúriaiak és tajvaniak egyszerübb, fizikai munkát igénylö feladatokat vállaltak. Az 1970-es, 1980-as években tajvaniak érkeztek a mezőgazdaságot elhagyó, a több lehetőséggel, szabadabb életfeltételekkel kecsegtető városi életet választó fiatal japánok helyére. A társadalmi szokások, hagyományok miatt a beházasodó fiatal kínai társadalmi elfogadottsága nagyobb vidéken, mint a városokban. Ebben az időszakban növekedett az illegálisan érkezők száma, ami a vízumrendszer újraszabályozásához vezetett. A következő bevándorlási hullám az 1980-as években a külvilág felé nyitó kínai politikához köthető. Az utóbbi két évtizedben, a magasabb életszínvonal, a több lehetőség reményében érkezők főbb foglalkoztatási területe a mezőgazdaság és az egészségügy. (Sugimoto 2010) A 2010-2016 közötti enyhe fogyást követően, 2016-ban a tajvaniakkal együtt közel 700 ezer kínai élt a szigetországban. Napjaikban ők a külföldi munkavállalók legnépesebb csoportja, megelözve a létszámban fokozatosan csökkenő koreaiakat. (1.táblázat, 2.ábra)

A Fülöp-szigetekröl érkezők alkotják az ázsiaiak harmadik legnépesebb közösségét. A 20102016 közötti időszakban, 2012-es mélyponttal, enyhén növekszik lélekszámuk, 2016-ban meghaladta a negyedmilliót. Az utóbbi két évtized vietnámi nyitása lehetővé tette a társadalmi, gazdasági hátrányokat nagyobb mértékben felvállaló, gyorsan növekvő kivándorlást. Az elemzett időszakban látványosan növekvő számuk megközelítette a 200 ezret, a változás dinamikáját előrevetítve, napjainkban ők lehetnek a harmadik legnépesebb ázsiai közösség Japánban. (1.táblázat, 2.ábra) 


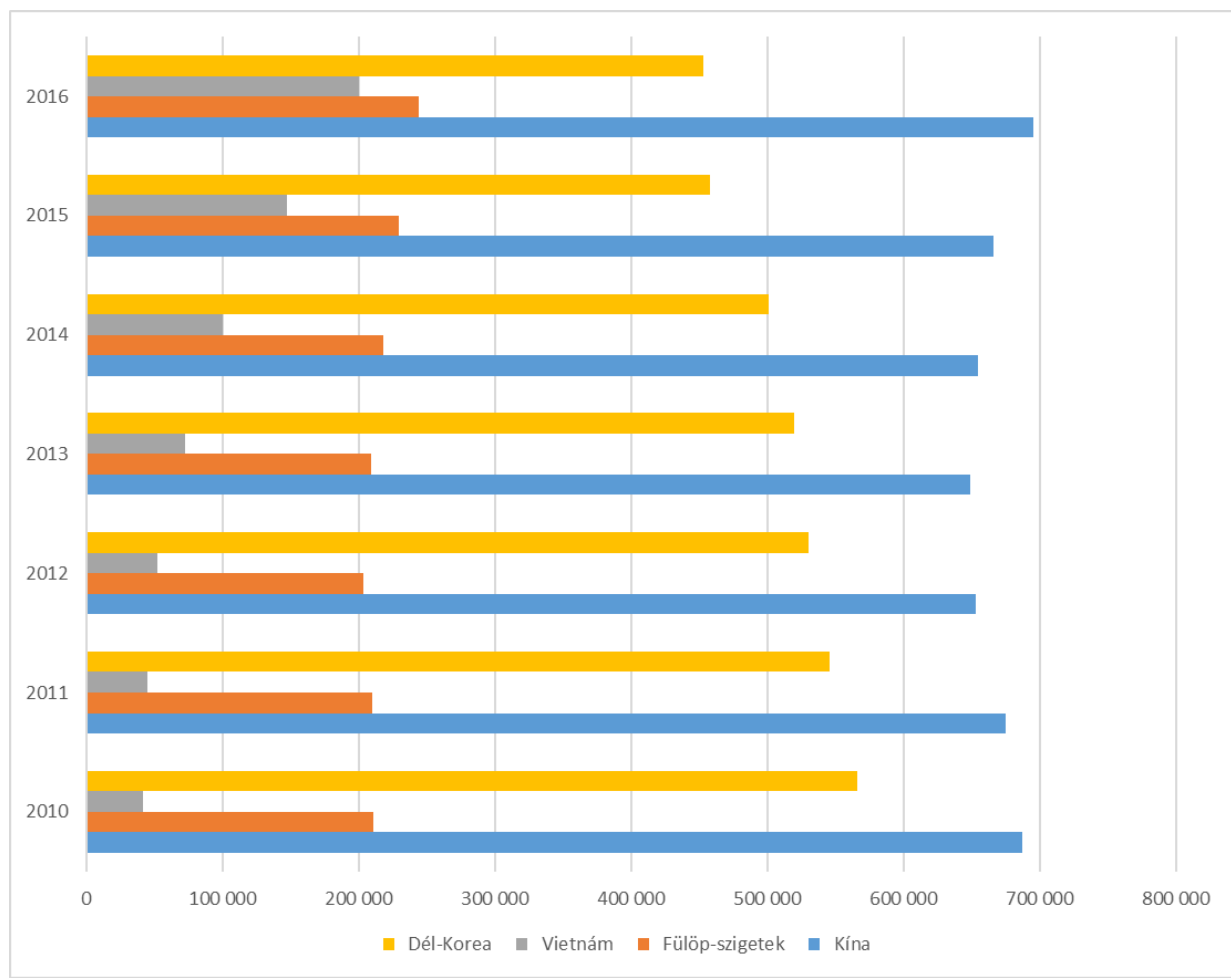

2.ábra: Ázsiai országokból érkezett, hosszú ideig vagy véglegesen Japánban tartózkodó legnépesebb külföldiek 2010-2016 között.

A www.stat.go.jp adatai alapján szerkesztette Deák Tamás

8 és 53 ezer közötti lélekszámot mutattak ki a statisztikák a Tajvanról, Thaiföldröl, Indonéziából, Indiából, Mianmarból, Pakisztánból, Sri Lankáról és Bangladesből érkezettek esetében, az indiaiak és az indonézek jelentős számbeli növekedésével a 2010-2016 közötti időszakban. 6 és 9 ezer közötti a malájok és a mongolok, 5 ezer alatti az irániak, szingapúriak és a kambodzsaiak lélekszáma. (1. táblázat) A fejlett Tajvan és Szingapúr többnyire magasan képzett szakembereket, a fejlődésben levő, vagy gyengén fejlett országok nagyobbrészt mezőgazdasági, ipari munkásokat bocsájtanak a szigetország munkaerőpiacára.

\section{Amerikából érkező munkavállalók}

50 ezer körüli az Egyesült Államokból érkezett, magasan képzett szakemberek létszáma, 10 ezer kanadai és 2 ezer mexikói tartózkodik a távolkeleti országban. (1.táblázat)

Japán legnépesebb amerikai közössége a braziloké. Az 1800-as évek végén, 1900-as évek elején a brazíliai kávéültetvényeket nagy számban elhagyó olasz és francia munkaerő gyors pótlására volt szükség. A korabeli bizonytalan kínai lehetőség helyett a válságot japán munkaerővel oldották fel. (Herbert 1995) 1908-1923 között 33 ezren, 1940-re pedig 205 ezren érkeztek, ami a korabeli brazíliai lakosság 0,5\%-át jelentette. Az 1970-es években a japán társadalom már nem tudta biztosítani a szükséges munkaeröt a gyorsan fejlődő gazdaság számára. A korabeli Német Szövetségi Köztársasághoz hasonlóan, itt is elkezdödött az anyaországból kivándoroltak leszármazottjainak hazahívása. Elkezdödött az alacsonyabb fejlettségü Brazíliában, Peruban élö japán leszármazottak (a japán megnevezés szerint „Nikkei”-ek) visszavándorlása. Többségük Honshu szigetén telepedett levő, gépipari összeszerelő munkásként (pl.: a Toyota gyáraiban), építőipari, mezőgazdasági alkalmazottként dolgozott. Tovább erősítette a 
„Szívóhatást” az 1990-es bevándorlási törvénymódosítás. 2010-2014 között lélekszámuk csökkent, majd 2016-ban meghaladta a 180 ezret. Sokak számára vonzó napjaink brazil gazdasági fejlödése, de túlnyomó többségük Japánban marad, kevesen választják a szezonális ingázás lehetőségét. Napjainkban növekszik a brazíliai „Nikkei” lakosság száma (másfél millió), de csökken a népességen belüli arányuk. A második legnépesebb dél-amerikai közösséget a brazíliaiakhoz hasonló történelmű, 50 ezres lélekszámú peruiak alkotják. (Carvalho 2003) (1.táblázat, 3.ábra)

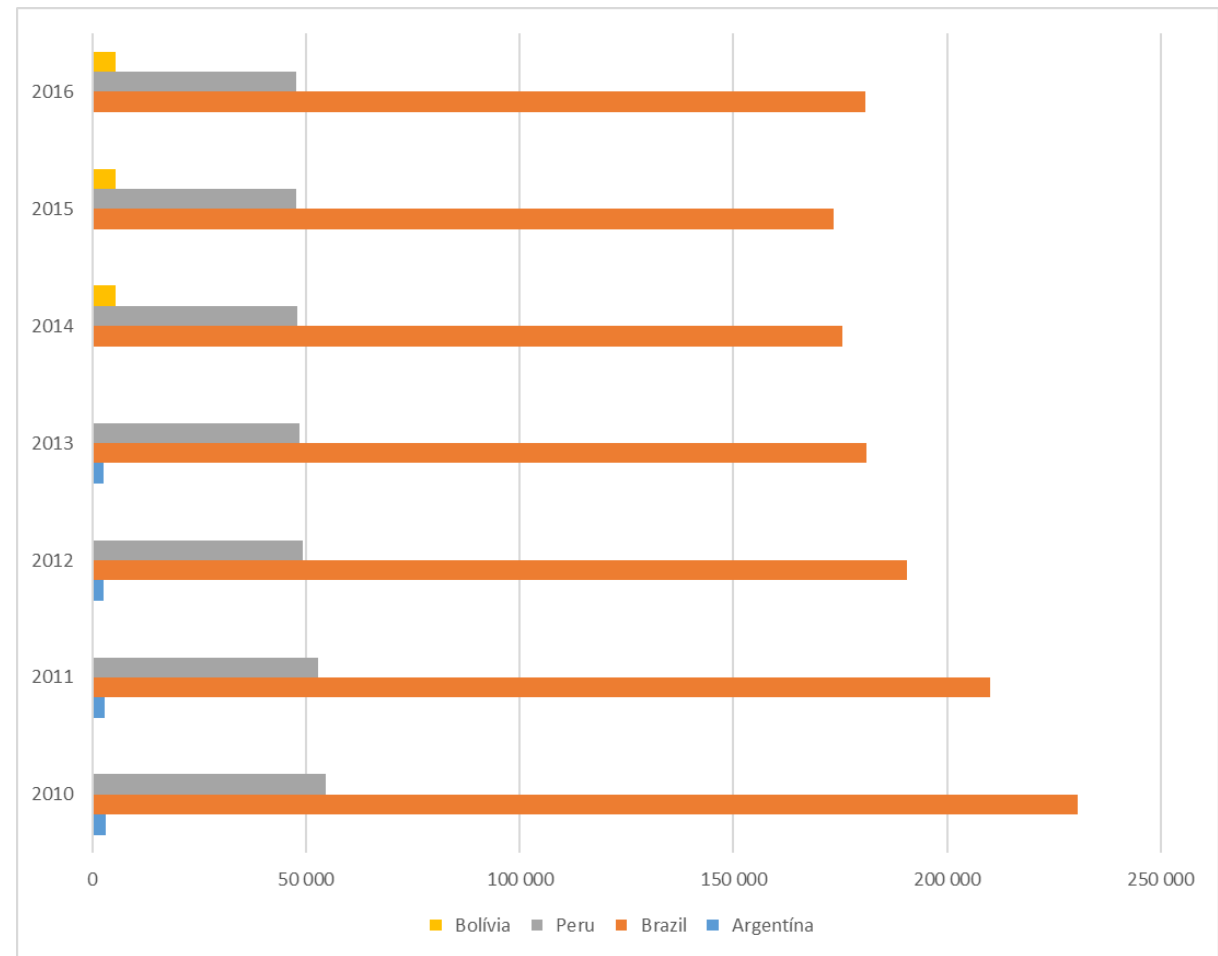

3.ábra: Dél-Amerikából érkezett, hosszú ideig vagy véglegesen Japánban tartózkodó legnépesebb külföldiek 2010-2016 között.

A www.stat.go.jp adatai alapján szerkesztette Deák Tamás

\section{Más kontinensekröl érkezö bevándorlók}

Japán elszigeteltsége, gazdasági lemaradása, a háborúk, a nagy földrajzi távolságok, a korlátozott közlekedési lehetőségek nem kedveztek a távolabbi kontinenseken élők bevándorlásának. Az 1950-es évektől érkeztek jelentősebb számban az Egyesült Államokból és Nyugat-Európából elsősorban magas képzettségü munkavállalók. Letelepedési célterületük a leggazdagabb nagyvárosok (Tokió, Kyoto, Osaka, Kobe). (Carvalho 2003)

Legjelentősebb európai kibocsájtó országok az Egyesült Királyság, Franciaország, Oroszország, Németország, Olaszország és Spanyolország. A britek nagyobb számú jelenléte részben a történelmi kapcsolatokkal magyarázható. A volt kommunista országok közül Romániából, Ukrajnából és Lengyelországból 1500-2500 munkavállaló érkezett. (1.táblázat)

Hasonló számú nigériai, ghánai és egyiptomi él a szigetországban, mindazok ellenére, hogy afrikai állampolgárok számára nagyon körülményes a munkavállalás Japánban.

2010-2016 között 10 ezer ausztrál, 2 és fél ezer újzélandi élt Japánban. (1.táblázat) 
Észak-magyarországi Stratégiai Füzetek XVII. évf. $\diamond 2020 \diamond 2$

1.táblázat: Az össznépesség és a külföldiek száma 2010-2016 között Japánban (www.stat.go.jp alapján).

\begin{tabular}{|c|c|c|c|c|c|c|c|}
\hline & 2010 & 2011 & 2012 & 2013 & 2014 & 2015 & 2016 \\
\hline $\begin{array}{c}\text { Összes } \\
\text { külföldi }\end{array}$ & 2134151 & 2078508 & 2033656 & 2066445 & 2121831 & 2232189 & 2382822 \\
\hline Japán & 125922849 & 125755492 & 125559344 & 125347555 & 125115169 & 124862811 & 124550178 \\
\hline $\begin{array}{c}\text { Teljes } \\
\text { népesség }\end{array}$ & 128057000 & 127834000 & 127593000 & 127414000 & 127237000 & 127095000 & 126933000 \\
\hline Ázsia & 1681469 & 1653679 & 1638344 & 1676140 & 2121831 & 2232189 & 2382822 \\
\hline Banglades & 10175 & 9413 & 8622 & 8822 & 9641 & 10835 & 12374 \\
\hline Dél-Korea & 565989 & 545401 & 530046 & 519737 & 501230 & 457772 & 453096 \\
\hline $\begin{array}{c}\text { Fülöp- } \\
\text { szigetek }\end{array}$ & 210181 & 209376 & 202974 & 209137 & 217585 & 229595 & 243662 \\
\hline India & 22497 & 21501 & 21653 & 22522 & 24524 & 26244 & 28667 \\
\hline Indonézia & 24895 & 24660 & 25530 & 27210 & 30210 & 35910 & 42850 \\
\hline Irán & 4841 & 4725 & 3996 & 3971 & Nincs adat & Nincs adat & Nincs adat \\
\hline Kambodzsa & 2683 & 2770 & 2862 & 3082 & Nincs adat & Nincs adat & Nincs adat \\
\hline Kína & 687156 & 674879 & 652555 & 648980 & 654777 & 665847 & 695522 \\
\hline Malajzia & 8364 & 8136 & 7848 & 7970 & 8288 & 8738 & 9084 \\
\hline Mianmar & Nincs adat & Nincs adat & Nincs adat & Nincs adat & 10252 & 13737 & 17775 \\
\hline Mongólia & Nincs adat & Nincs adat & Nincs adat & Nincs adat & 5796 & 6590 & 7636 \\
\hline Nepál & Nincs adat & Nincs adat & Nincs adat & Nincs adat & 42346 & 54775 & 67470 \\
\hline Pakisztán & 10299 & 10849 & 10597 & 11119 & 11802 & 12708 & 13752 \\
\hline Sri Lanka & 9097 & 9303 & 8427 & 9191 & 10741 & 13152 & 17346 \\
\hline Szingapúr & 2512 & 2440 & 2135 & 2226 & Nincs adat & Nincs adat & Nincs adat \\
\hline Tajvan & Nincs adat & Nincs adat & 22773 & 33322 & 40197 & 48723 & 52768 \\
\hline Thaiföld & 41279 & 42750 & 40130 & 41204 & 43081 & 45379 & 47647 \\
\hline Üzbegisztán & Nincs adat & Nincs adat & Nincs adat & Nincs adat & 1329 & 1503 & 1874 \\
\hline Vietnám & 41781 & 44690 & 52364 & 72238 & 99865 & 146956 & 199990 \\
\hline Egyéb & 39720 & 42786 & 45832 & 55409 & Nincs adat & Nincs adat & Nincs adat \\
\hline $\begin{array}{c}\text { Észak- } \\
\text { Amerika }\end{array}$ & 64653 & 63250 & 61062 & 62745 & Nincs adat & Nincs adat & Nincs adat \\
\hline Kanada & 9995 & 9484 & 9006 & 9024 & 9286 & 9538 & 10034 \\
\hline Mexikó & 1956 & 1909 & 1935 & 1927 & 2033 & 2141 & 2304 \\
\hline U.S.A. & 50667 & 49815 & 48357 & 49979 & 51256 & 52271 & 53705 \\
\hline Egyéb & 2035 & 2042 & 1764 & 1815 & Nincs adat & Nincs adat & Nincs adat \\
\hline Dél-Amerika & 300142 & 277220 & 253199 & 243174 & Nincs adat & Nincs adat & Nincs adat \\
\hline Argentína & 3181 & 2970 & 2722 & 2664 & Nincs adat & Nincs adat & Nincs adat \\
\hline Bolívia & Nincs adat & Nincs adat & Nincs adat & Nincs adat & 5333 & 5412 & 5550 \\
\hline Brazília & 230552 & 210032 & 190581 & 181268 & 175410 & 173437 & 180923 \\
\hline Peru & 54636 & 52843 & 49248 & 48580 & 47978 & 47721 & 47740 \\
\hline Egyéb & 11773 & 11375 & 10648 & 10662 & Nincs adat & Nincs adat & Nincs adat \\
\hline Európa & 60975 & 58427 & 56891 & 59241 & 52361 & 56025 & 59183 \\
\hline Ausztria & 569 & 537 & 495 & 499 & Nincs adat & Nincs adat & Nincs adat \\
\hline Belgium & 697 & 689 & 655 & 625 & Nincs adat & Nincs adat & Nincs adat \\
\hline Dánia & 499 & 496 & 472 & 523 & Nincs adat & Nincs adat & Nincs adat \\
\hline $\begin{array}{c}\text { Egyesült } \\
\text { Királyság }\end{array}$ & 16044 & 15496 & 14652 & 14880 & 15262 & 15826 & 16454 \\
\hline Finnország & 599 & 604 & 620 & 618 & Nincs adat & Nincs adat & Nincs adat \\
\hline
\end{tabular}


Észak-magyarországi Stratégiai Füzetek XVII. évf. $\diamond 2020 \diamond 2$

\begin{tabular}{|c|c|c|c|c|c|c|c|}
\hline Franciaország & 9060 & 8423 & 8455 & 8877 & 9641 & 10672 & 11640 \\
\hline Hollandia & 1099 & 1097 & 917 & 953 & Nincs adat & Nincs adat & Nincs adat \\
\hline Írország & 1061 & 1065 & 1072 & 1039 & Nincs adat & Nincs adat & Nincs adat \\
\hline Lengyelország & 978 & 951 & 1007 & 1087 & 1110 & 1653 & 1420 \\
\hline Németország & 5971 & 5303 & 5223 & 5547 & 5864 & 6336 & 6773 \\
\hline Norvégia & 416 & 408 & 366 & 416 & Nincs adat & Nincs adat & Nincs adat \\
\hline Olaszország & 2731 & 2642 & 2629 & 2919 & 3267 & 3536 & 3824 \\
\hline Oroszország & 7814 & 7566 & 7295 & 7509 & 7859 & 8092 & 8306 \\
\hline Portugália & 465 & 454 & 407 & 426 & Nincs adat & Nincs adat & Nincs adat \\
\hline Románia & Nincs adat & Nincs adat & Nincs adat & Nincs adat & 2245 & 2408 & 2481 \\
\hline $\begin{array}{l}\text { Spanyol- } \\
\text { ország }\end{array}$ & 1907 & 1883 & 1822 & 2057 & 2309 & 2495 & 2750 \\
\hline Svájc & 1089 & 1011 & 937 & 966 & Nincs adat & Nincs adat & Nincs adat \\
\hline Svédország & 1553 & 1579 & 1677 & 1727 & 1874 & 1805 & 1794 \\
\hline Ukrajna & Nincs adat & Nincs adat & Nincs adat & Nincs adat & 1601 & 1699 & 1867 \\
\hline Egyéb & 8423 & 8223 & 8190 & 8573 & Nincs adat & Nincs adat & Nincs adat \\
\hline Afrika & 12130 & 11972 & 10879 & 11545 & Nincs adat & Nincs adat & Nincs adat \\
\hline Egyiptom & 1593 & 1382 & 1308 & 1537 & 1665 & 1747 & 1886 \\
\hline Ghána & 1883 & 1891 & 1729 & 1834 & 1915 & 2005 & 2148 \\
\hline Nigéria & 2729 & 2730 & 2377 & 2453 & 2518 & 2638 & 2797 \\
\hline Egyéb & 5925 & 5969 & 5465 & 5721 & Nincs adat & Nincs adat & Nincs adat \\
\hline Óceánia & 13548 & 12860 & 12535 & 12692 & Nincs adat & Nincs adat & Nincs adat \\
\hline Ausztrália & 9756 & 9166 & 8888 & 9014 & 9350 & 9843 & 10387 \\
\hline Új-Zéland & 3250 & 3146 & 3109 & 3109 & 3119 & 3152 & 3239 \\
\hline Egyéb & 542 & 548 & 538 & 569 & Nincs adat & Nincs adat & Nincs adat \\
\hline
\end{tabular}

Japánban a külföldiek össznépességen belüli aránya 2010-ben 1,7\% (2,1 millió), 2012-ben 1,6\% (2 millió), 2014-ben 1,7,\% (2,1 millió), 2016-ban közel 1,9\% (2,4 millió), napjaikban 2\% feletti. A külföldiek többsége a fóvárosba, a nagyvárosokba, a gazdagabb prefektúrákba telepszik le. (www.stat.go.jp). (5.ábra) 


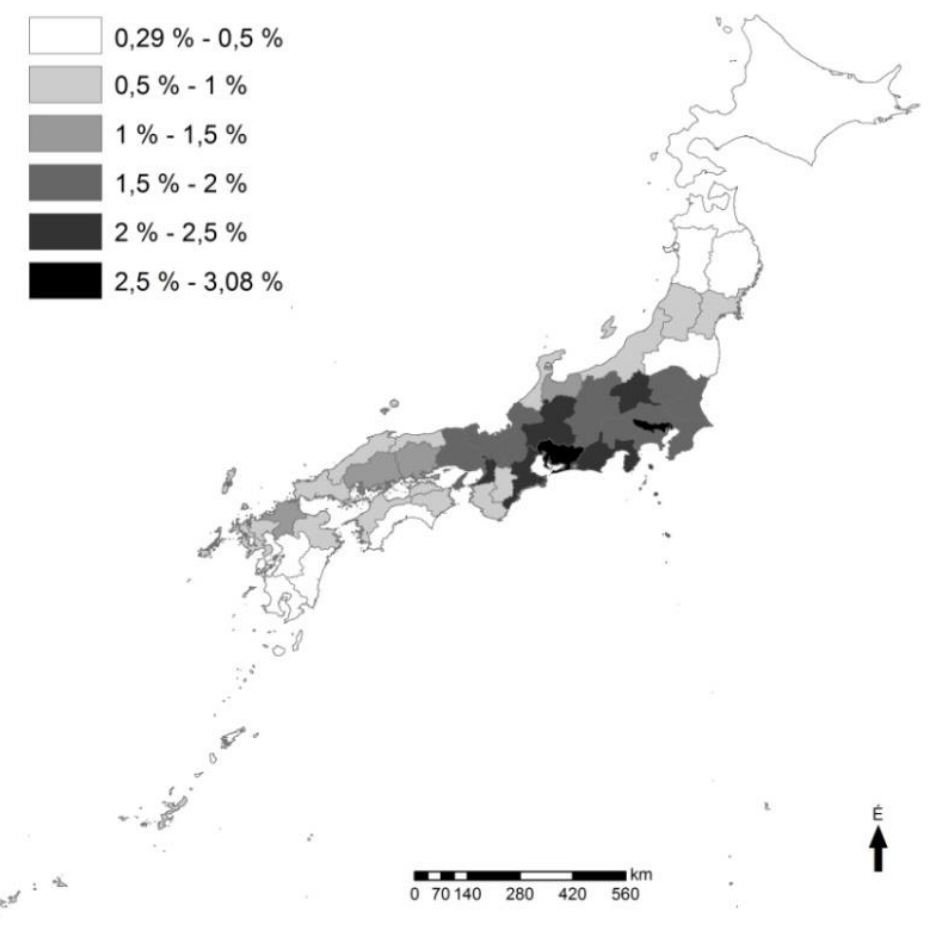

5.ábra: A külföldiek aránya Japán prefektúráiban 2013-ban

A www.stat.go.jp adatai alapján szerkesztette Deák Tamás

Az 1. táblázat adatai szerint a tanulmányozott időszakban a kibocsájtó országok jelentős részénél a mélypontot 2012 jelenti, majd ezt követi egy jelentős növekedés (4.ábra)

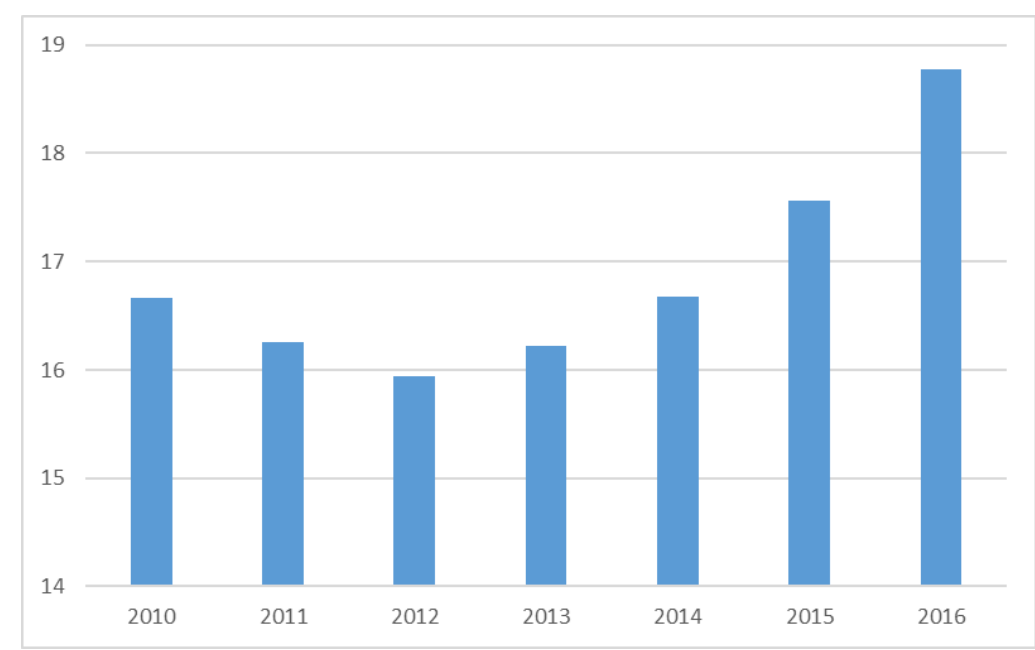

4.ábra: 1000 japán lakosra jutó, hosszú ideig vagy véglegesen Japánban tartózkodó külföldiek száma. A www.stat.go.jp adatai alapján szerkesztette Deák Tamás

A 2011. március 11.-i földrengés és szökőár erőteljes pusztítást végzett az ország északkeleti részében. A Fukushimai atomerőmü balesete után japánok és külföldiek tömegesen hagyták el a térséget. Ez az eseménysor szerepet játszott a vendégmunkások országos szintü számbeli 
csökkenésében is. A helyzet normalizálódása után, 2012-öt követően ismét fokozatosan növekedett a külföldiek száma.

A 2. világháború utáni gazdasági fejlődés és nyitás évtizedeiben a tömeges bevándorlással egyidőben jelentős számú, magasan képzett japán fiatal talál munkalehetőséget a fejlett nyugaton, túlnyomórészt az Egyesült Államokban.

Sajátos színfoltot képvisel a mai japán társadalomban az 1,3 milliónyi őshonos kisebbség. A 2008-ban őshonos etnikumként elismert, saját nyelvvel (Ajnu) és vallással (animizmus) rendelkező ajnuk létszáma lecsökkent 20-25 ezerre. Ugyancsak saját nyelvük, kultúrájuk van a sintoizmus egyik változatát követő okinawaiaknak. A 2. világháború alatt komoly veszteségeket megélt szigetcsoporton 138 ezer körüli a lélekszámuk. A császári adminisztráció által erőszakkal terjesztett buddhizmusnak ellenszegülö, állattenyésztéssel, hentességgel foglalkozó népcsoportot „,burakumin”-nak nevezi a többségi társadalom. A napjaikig fennmaradt, az országban szétszórtan élő közösségük létszáma közel 900 ezer. (Sugimoto 2010).

\section{Összegzés}

Japán történelmében a leglátványosabb fejlödés időszakát a 2. világháborút követő újjáépítés évtizedei jelentették. Az ország gazdasága a változó világgazdasági körülményekhez, a társadalom a nyugati típusú életvitelhez, szokásokhoz, magatartáshoz igazodott.

Látványos gazdasági fejlődésének munkaerő igényét részben külföldi munkavállalókkal biztosítja. A legnépesebb külföldi közösségek a kevésbé fejlett közeli, jelentös történelmi kötődésű országokból származnak. 700 ezer kínai és 450 ezer dél-koreai él a szigetországban, növekszik a távolabbi ázsiai országokból származók száma.

A folyamat globalizálódását mutatja a távolabbi kontinensekről származó közösségek jelenléte. Az 1970-es évektől, a kiszámíthatóbb élet, a magasabb életszínvonal biztosításának lehetősége, a vízumszabályok enyhítése felerősítette a Brazíliába és Peruba kitelepedett japánok leszármazottjainak visszavándorlását. Számukra a nyelv, kultúra ismerete hatékonyabb társadalmi integrációt, az állampolgárság megszerzésének könnyebb lehetőségét biztosítja. Az Amerikai Egyesült Államokból, Kanadából, Ausztráliából és Nyugat-Európából többnyire magasan képzett szakemberek érkeznek. Az utóbbi évtizedben növekedett az európai volt kommunista országokból származó vendégmunkások száma. A külföldiek munkavállalása az állam által ellenőrzött, jól körül határolt jogi keretek között történik. A külföldiek többsége az ország gazdasági centrumtérségeiben, a fóvárosban és a nagyvárosokban dolgozik.

A népesedési és gazdasági folyamatok ismeretében a külföldiek további szám- és aránybeli növekedése várható, de ez a növekedés nem vezet az ország és az összlakosság kulturális jellegzetességeinek megváltozásához, kicserélődéséhez.

\section{Köszönetnyilvánítás}

"A cikkben/elöadásban/tanulmányban ismertetett kutató munka az EFOP-3.6.1-16-2016-00011 jelü „Fiatalodó és Megújuló Egyetem - Innovatív Tudásváros - a Miskolci Egyetem intelligens szakosodást szolgáló intézményi fejlesztése" projekt részeként - a Széchenyi 2020 keretében - az Európai Unió támogatásával, az Európai Szociális Alap társfinanszírozásával valósul meg".

\section{Irodalomjegyzék}

CARVALHO, D. (2003): Migrants and Identity in Japan and Brazil, The Nikkeijin - Routledge Curzon, Taylor \& Francis Group, London, pp. 3-35, 79-115 
DEÁK T. - ELEKES T. (2019): Nyersanyag-gazdaság-népesség kapcsolatrendszerének néhány sajátossága Japánban az utóbbi száz évben. Müszaki Földtudományi Közlemények, 88. kötet, 2. szám, Miskolci Egyetemi Kiadó, pp. 111-116

HAYASHI, F. (2001): The 1990s in Japan: A Lost Decade. University of Tokyo, Tokyo. pp. 3-7

HERBERT, K. (1995): European and Asian Migration to Brazil. In: R. Cohen (szerk.) The Cambridge Survey of World Migration, Cambridge: Cambridge University Press, pp. $19-208$

HORVÁTH G. (1998): A Japán-szigetvilág. In: PROBÁLD F. - HORVÁTH G. (szerk.): Ázsia, Ausztrália és Óceánia földrajza. ELTE Eötvös Kiadó, Budapest. pp.234-276

HORVÁTH G. - SZABÓ P. - WILHELM Z. (2010): Japán. In: TÓTH J.(főszerk.): Világföldrajz. Akadémiai Kiadó, Budapest. pp. 951-960

IIJIMA, M. (2015): Japanese Women in Agriculture - Overview. Global Agricultural Information Network, USDA Foreign Agricultural Service, pp. 1-5

MIZUUCHI, T. (2003): The Historical Transformation of Poverty, Discrimination, and Urban Policy in Japanese City: The Case of Osaka. Osaka City University, Department of Geography, Japan-Osaka. pp. 22-23

PALANOVICS N. (2006): „Új áramlatok Japán hivatalos fejlesztési támogatásainak (ODA) rendszerében". Kül-Világ 3(2). http://www.freeweb.hu/kulvilag/2006/02/palanovics.pdf

SORENSEN, A. (2002): The Making of Urban Japan, Cities and planning from Edo to the twentyfirst century. Taylor \& Francis Group, London and New York. pp. 151-200

SUGIMOTO, Y. (2009): The Cambridge Companion to Modern Japanese Culture - Cambridge University Press, Port Melbourne, Australia, pp. 76-90, 147-163, 182-196

SUGIMOTO, Y. (2010): An Introduction to Japanese Society, Third Edition - Cabridge University Press, New York, USA, pp. 189-218

SZENTES T. (2002): A II. világháború után kialakult nemzetközi gazdasági rend és a változó világgazdaság. In: BLAHÓ, A. (szerk.): Világgazdaságtan. Globális fejlődés, gazdaságdiplomácia. Aula, Budapest, pp.259-299.

SZENTES T. (2011): Fejlődés-gazdaságtan. Akadémiai Kiadó, Budapest. 531 p.

WALLERSTEIN I. (1983): A modern világgazdasági rendszer kialakulása. Gondolat, Budapest. $782 \mathrm{p}$.

WOOLLEY, P. J. (2005): Geography \& Japan's Strategic Choices From Seclusion to Internationalization - Potomac Books, Inc. Washington, D.C. pp. 43-58, 70-101 